\title{
MARCIN IMACH
}

\section{Religie i pokój w Iraku}

Teren Bliskiego Wschodu od wielu dziesięcioleci jest tym miejscem na świecie, gdzie interesy największych religii wydają się być szczególnie trudne do pogodzenia.

Zdarza się tam czasami usłyszeć stwierdzenie, iż dusza muzutmanina utkana jest $z$ wersetów Koranu. W zasadzie wszystko, co dotyczy Koranu, było i jest tam nadal święte. Być może jest to jedno z twierdzeń, które uniemożliwia pojednanie pomiędzy religiami na tym terenie. Równocześnie jednak teologowie muzułmańscy przyznają, iż Koran jest dla nich tym, czym Chrystus dla chrześcijan Słowem Bożym. Często czynią także porównanie między Marią Dziewicą a duszą Proroka. Ona daje światu Jezusa - Słowo Boże, Prorok zaś: Koran - Słowo Allacha ${ }^{1}$. Już tylko na tym przykładzie widać pewną niejednoznaczność sytuacji religijnej, która może wystąpić na Bliskim Wschodzie.

$\mathrm{Z}$ kolei pewna konsekwencja $\mathrm{w}$ wyznawaniu wiary przez muzułmanów, szczególnie właśnie z tego terenu, doprowadziła u nich do zdecydowanego wzrostu liczby wiernych. Bez wątpienia interesujące mogą się wydawać dane liczbowe podawane przez K. Kościelniaka. Jeżeli przyjąć, że w 1901 r. na świecie żyło około $558 \mathrm{mln}$ chrześcijan, to muzułmanów było wówczas $200 \mathrm{mln}$. Z kolei po upływie wieku, w $2001 \mathrm{r}$. chrześcijan było $2020 \mathrm{mln}$, a muzułmanów $1201 \mathrm{mln}^{2}$.

W takich okolicznościach na terenie Bliskiego Wschodu żyje od stuleci ludność chrześcijańska. Zna ona miejscowe języki, tradycje, zwyczaje, mental-

Marcin I M A C H, doktorant na Wydziale Teologicznym Uniwersytetu Śląskiego w Katowicach; e-mail: sonimach@op.pl

${ }^{1}$ E. W n u k-Li s ow ska: Wiara $i$ gnoza wi slamie. W: Między wiara a gnoza. Red. M. J a k u b c z a k, M. S a c h a - P i e k ł o. Kraków 2003 s. 268.

${ }^{2}$ K. K o ś c i e 1 n i a k: Chrześcijaństwo w spotkaniu z religiami świata. Kraków 2002 s. 369. 
ność i przyzwyczajenia. Trzeba jednak zaznaczyć, że ludność ta stanowi od wieków mniejszość, a konkretnie od czasów, kiedy na tych terenach rozprzestrzenił się islam ${ }^{3}$.

Wśród państw z tego terenu istnieje takie, gdzie jeszcze do końca XX w. pod rządami silnej ręki Saddama Husajna można było odnieść wrażenie, że relacje chrześcijańsko-muzułmańskie są możliwe do pogodzenia. Po upadku reżimu okazało się jednak, jak wiele sprzecznych interesów zostało umiejscowionych w tym niejako sztucznym państwie. Wydarzenia takie, jak powstanie Państwa Islamskiego, miały prawdopodobnie jednak swoje przyczyny w znacznie wcześniejszym okresie. Dlatego też wydaje się interesującą sprawą poznanie sytuacji, szczególnie religijnej tego kraju. W tym celu przedstawimy w zarysie historię terenu, na którym znajduje się współczesny Irak. Następnie ukażemy sytuację religijną z uwzględnieniem pewnej obyczajowości większości religijnej, jaką na tym terenie są muzułmanie. Umożliwi to ukazanie losów tamtejszych chrześcijan w kolejnym punkcie. Informacje te - jak się wydaje - powinny pomóc znalezienie odpowiedzi na pytanie, dotyczące przyczyn napiętej sytuacji religijnej w Iraku, która doprowadziła do powstania Państwa Islamskiego.

\section{Historia Iraku}

Dla lepszego zrozumienia wydarzeń mających miejsce w Iraku, należy rozpocząc od ukazania go jako sąsiada znaczących państw na terenie Bliskiego Wschodu. Trzeba zaznaczyć, że kraj ten graniczy od południa z Arabią Saudyjską i Kuwejtem, na wschodzie z Iranem oraz Azerbejdżanem, na zachodzie z Jordanią i Syrią, na północy z Turcją. Natomiast geograficznie teren ten jest dość zróżnicowany. W rejonie trójkąta granicznego pomiędzy Irakiem, Syrią i Turcją na obszar międzyrzecza przenika jeden z łańcuchów Armeńskiego Tauru - Dżabal Abidżad. Z kolei łańcuchy górskie są przecinane górskimi rzekami i potokami. Odmiennie wygląda sytuacja w zachodniej części kraju, gdzie znajdują się rozległe tereny pustynne ${ }^{4}$. Trzeba też dodać, iż współcześnie Irak położony jest nad Zatoką Perską w południowo-zachodniej Azji, na obszarze Bliskiego Wschodu, o powierzchni 438 tys. $\mathrm{km}^{2}$. Jego obecną liczbę mieszkańców określa się na 22,5 mln. Natomiast stolicą kraju jest Bagdad, w którym zamieszkuje 4,5 mln ludzi 5

Chcąc zaznajomić się chociażby w dużym zarysie $\mathrm{z}$ historią tego terenu, trzeba cofnąc się do starożytności. Otóż obszar ten, to bez wątpienia sumeryjska

${ }^{3}$ P. S i n i s c a l c o: Starożytne Kościoly Wschodnie. Historia i Literatura. Wydawnictwo Petrus. Kraków 2013 s. 7-9.

${ }^{4}$ J. B r a u n: Mezopotamia. Wrocław 1971 s. 28-30.

${ }^{5}$ M. B r y l e w: Irak 2003-2005. Toruń 2011 s. 14n. 
kolebka cywilizacji, a według podań biblijnych, nawet całej ludzkości. W tym bowiem miejscu umieszczono Raj. Od kilku tysięcy lat rozwijały się na tym obszarze wielkie cywilizacje świata starożytnego. Zmagające się potęgi militarne często niszczyły ten kraj. Jednak w okresach pokoju kwitła tu nauka, literatura i sztuka. Wznoszono wówczas wspaniałe budowle, które zadziwiają do dzisiaj ${ }^{6}$.

Trzeba przypomnieć, że na ziemiach współczesnego Iraku powstała najstarsza cywilizacja w dziejach ludzkości - Mezopotamia. Do czasów obecnych wszyscy Irakijczycy są z tego dumni. Pomiędzy rzekami Tygrys i Eufrat w okresie V i IV tys. lat przed Chrystusem funkcjonowało państwo Sumerów, a później kolejne wielkie cywilizacje, jak Akad, Asyria, Babilon. W VI w. przed Chrystusem wspomniany Babilon został zajęty przez Persów. Następnie po 200 latach przybył tam Aleksander Macedoński. Z kolei w III w. przed Chrystusem tereny te przeszły pod władanie Partów. Nie był to jednak koniec bujnych dziejów terenu określanego dzisiaj mianem Iraku. Otóż w II w. po Chrystusie obszary te opanowali Rzymianie. Po kolejnych stu latach wyparli ich Persowie ${ }^{7}$. Zatem już od czasów starożytnych tereny współczesnego Iraku były przenikane przez różne kultury, a tym samym również różne religie. Nie można jednak stwierdzić, że to właśnie religie były przyczyną kolejnych zmian władzy na tym terenie. To zdecydowanie czynnik polityczny, narodowościowy decydował o zmianach władających tym terenem.

Powyższe informacje potwierdza S. Zawadzki pisząc, iż krótki okres od VII do VI w. przed Chrystusem jest uważany za jeden z najważniejszych w dziejach Mezopotamii. Po kilku wiekach hegemonii, w 609 r. przed Chrystusem, upadło państwo asyryjskie. Jego miejsce zajęło państwo nowobabilońskie. Od Chaldejczyków bywa ono także nazywane chaldejskim. Była to jedna z dwóch głównych grup etnicznych zamieszkujących wówczas te tereny. Blisko z nimi spokrewnieni byli Asyryjczycy. W 539 r. przed Chrystusem nastąpiła już likwidacja państwa nowobabilońskiego. W okresie tym powstało jednak wiele wspaniałych przedsięwzięć budowlanych ${ }^{8}$.

Z kolei chrześcijanie znajdowali się w Arabii przynajmniej od V w. W tym okresie rządził król himjarycki, Dhu Nuwas, który przeszedł na judaizm i rozpoczął ich prześladowanie. Dotyczyło ono głównie chrześcijan z Nadżranu, miejscowości na pograniczu dzisiejszego północnego Jemenu. Prześladowanie, które miało miejsce w 523 r., pociągnęło za sobą wiele ofiar wśród chrześcijan. Wówczas do Arabii południowej chrześcijaństwo przenikało głównie $\mathrm{z}$ Abisynii/Etiopii, gdzie już od IV w. istniały Kościoły chrześcijańskie. Potwierdza to fakt zorganizowania wyprawy wojennej przez króla Ellesbasa z Etiopii, podjętej

\footnotetext{
${ }^{6}$ J. G ł o d e k: Irak. Warszawa 1982 s. 5.

${ }^{7}$ S. Z a w a d z k i: Mane Tekel Fares. Poznań 1996 s. 9.

${ }^{8}$ Tamże.
} 
w obronie chrześcijan z Arabii południowej. Zakończyła się ona sukcesem i udało się ustanowić w Arabii południowej etiopskie namiestnictwo, które wytrwało do 575 r. Chrześcijański namiestnik wybudował kościoły w Merib i Sanie oraz przedsięwziął wyprawę przeciw Mekce. Równocześnie cesarz bizantyjski zlecił zbudowanie katedry w Sanie. Miejscowość ta została obrana wówczas za stolicę przez chrześcijańskich namiestników. Można byłoby zatem przypuszczać, że to religia w tym przypadku była niejako motorem napędowym wojen na tych terenach. Trzeba jednak pamiętać, że władcy decydujący się na wyprawy, nawet w obronie wiary, którą wyznawali, nie czynili tego całkowicie bezinteresownie. Ich łupem stawały się przecież ogromne ilości niewolników, kosztowności itp.

Czynniki te spowodowały prawdopodobnie, że we wspomnianym 575 r., za sprawą porażek militarnych, Arabia południowa stała się prowincją perską. Natomiast między 753-775 r. katedra w Sanie została zburzona ${ }^{9}$. W ten sposób na tereny obecnego Iraku przenikało chrześcijaństwo od południa, od strony obecnej Arabii Saudyjskiej. Równocześnie, szczególnie od V w., na tereny te napływali z północnego zachodu chrześcijanie, którzy byli często prześladowani przez Bizancjum jako heretycy. Byli to głównie nestorianie.

Informacje te potwierdza również B. Doe, przyznając, iż rozpowszechnienie chrześcijaństwa na terenie Arabii południowej było wysiłkiem misjonarzy wysłanych w IV w. z Konstantynopola i Tyru. Liczba nawróconym dzięki tej akcji była znaczna. Do najwybitniejszych nowych chrześcijan należał król Himjaru Saran Juhanim. Równocześnie około 350 r. został ochrzczony król Ezana z Aksumu w Etiopii. W tym czasie w Arabii ostoją chrześcijaństwa stał się wspomniany już Nadżran. Jednakże pewna wrogość niektórych miejscowych kręgów ludności wobec chrześcijaństwa powodowała wzrastanie w siłę judaizmu. Wynikało to być może z faktu, iż według tradycji mieszkańcy Nadżranu byli tak fanatyczni, że każdego w obrębie miasta nawracali na chrześcijaństwo. Jest to na pewno argument, który mógłby stanowić o tym, że religie na tym terenie przyczyniały się do wzrostu napięć społecznych.

Trzeba też zauważyć, iż chrześcijaństwo na tym terenie było wówczas tak silne, że w 525 r. na króla południowo-zachodniej Arabii został wyznaczony chrześcijański wielmoża. Jednak wobec tryumfu chrześcijaństwa na tych terenach Persowie mocniej zaczęli popierać judaizm ${ }^{10}$. Potwierdza to niejako tezę o możliwym południowym oddziaływaniu chrześcijaństwa na Irak. Trzeba też wspomnieć, iż nieco wcześniej bo $\mathrm{w} \mathrm{V}$ w. po Chrystusie narodził się w połu-

\footnotetext{
9 J. G n il k a: Biblia a Koran. Podobieństwa i różnice. Kraków 2005 s. 15n.

${ }^{10}$ B. D o e: Poludniowa Arabia. Warszawa 1979 s. 43n.
} 
dniowym Iraku system mandejski, który również oddziaływał na sytuację na terenie obecnego Iraku ${ }^{11}$.

Jednakże rozbicie państwa Sassanidów przez Arabów w latach 638-650 doprowadziło do sytuacji, w której perskie prześladowania chrześcijan na tym terenie uległy pewnemu złagodzeniu. Muzułmanie wycięli głównie zwolenników Zaratustry ${ }^{12}$, pozostawiając chrześcijan jako ludność drugiej kategorii. Informacje takie można znaleźć także w publikacjach M. Kubiaka, który przyznaje, że w latach 634-641 tereny te zostały zdominowane przez Arabów. Zapanował wtedy islam. Od VIII w. po Chrystusie rejony te były nawet przez kilka wieków centrum muzułmańskiego imperium. Z kolei w połowie VIII w. po Chrystusie zostało wybudowane przez Al-Mansura, władcę z dynastii Abbasydów miasto Bagdad $^{13}$.

Trzeba też wspomnieć, iż nieco później, bo pomiędzy VIII a IX w. znana była już nazwa Irak. Stosowano ją wówczas w odniesieniu do krainy geograficznej czy historycznej. Jednak nie była to nazwa państwa. W tym też okresie, czyli od VIII w., a zatem od kiedy Bagdad istnieje, prawie zawsze rządzili na tym terenie sunnici. Szyici rządzili w Iraku zaledwie przez kilkanaście lat. Było to w czasie, gdy terytorium Iraku znajdowało się w granicach Imperium Perskiego. Była to jednak władza obca. Wynikało to w dużej mierze $\mathrm{z}$ tego, że szyici, jako odłam islamu zawsze byli niejako w opozycji, byli tymi słabszymi. Irak w dużej mierze pozostawał szyicki od samego początku islamu, czyli od VII w. Należy tu wspomnieć, iż Muhammad Bakir al-Hakim polityk i teolog, stawiał sobie za cel stworzenie szyickiego państwa dla Arabów ${ }^{14}$. Wszystko to miało jednak miejsce przy znaczącej obecności miejscowych chrześcijan, głównie nestorian.

W XIII w., na objęte w ten sposób islamem tereny Iraku, zaczęły napływać chrześcijańskie misje, które zainicjowały zakony. Dominowali tutaj franciszkanie i dominikanie. Na tereny te przyjeżdżali również misjonarze św. Wincentego à Paulo. Niestety działalność ta kończyła się przeważnie wymuszanym na nich odwrocie. Często bywała okupiona także śmiercią męczeńską ${ }^{15}$.

Z kolei 13 lutego 1258 r. muzułmańskich mieszkańców Iraku dotknęła tragedia. Wtedy to Mongołowie opanowali Bagdad i w ciągu kilku dni wycięli w pień kilkaset tysięcy mieszkańców. Oszczędzono jedynie chrześci-

${ }^{11}$ W. F o x w e 11 - A 1 b r i g h t: Od epoki kamiennej do chrześcijaństwa. Tłum. E. Z w o 1 s k i. Warszawa 1967 s. 294.

${ }^{12}$ N. Z e r n o v: Wschodnie chrześcijaństwo. Tłum. J. Ło ś. Warszawa 1967 s. 97.

${ }^{13} \mathrm{M}$. K u b i a k: Kulturowo-religijne aspekty sytuacji polityczno-militarnej w Iraku. W: Irak 2004, Ku normalności. Materialy z konferencji naukowej zorganizowanej z inicjatywy i pod patronatem Ministerstwa Obrony Narodowej. Red. J. G o t o w a ł a. Warszawa 2004 s. 157n.

${ }^{14}$ M. D z i e k a n: Irak. Polityka i religia. Warszawa 2005 s. 249-253.

${ }^{15}$ W. P s u r e k: Ekspansja islamu w świecie. Katowice 2007 s. 146n. 
jan. Wynikało to z faktu, iż żona Hulagu-chana, władcy mongolskiego, była chrześcijanką ${ }^{16}$.

Przez kolejne stulecia na obszarze tym bardzo różnie układały się relacje pomiędzy religiami. Pewne zmiany nadeszły, gdy na terenie Iraku zostały odkryte ogromne złoża ropy naftowej. Zainteresowali się nimi wówczas przedsiębiorcy z wielu krajów. W tym okresie kraj podlegał Turcji, z którą w kwestii zasobów ropy naftowej rozmawiali Niemcy. Ostatecznie jednak po I wojnie światowej złoża zostały opanowane przez Anglików.

Warto zauważyć, że w okręgu mosulskim, w miejscowości Kirkuk, znajdują się największe złoża irackiej ropy. Wydobycie ropy naftowej rozpoczęło się w Kirkuku w 1927 r. Natomiast podczas II wojny światowej odkryto nowe, wielkie złoża pod Basrą ${ }^{17}$.

Właśnie w tym okresie na światowych mapach pojawił się Irak jako państwo. Miało to miejsce w 1921r. Wówczas na konferencji w Kairze utworzono królestwo Iraku, na czele którego miał stanąć probrytyjski król Fajsal Ibn Husajn. Trzeba zaznaczyć, iż wytyczenie granic tego państwa nastąpiło całkowicie z pominięciem praw plemiennych, etnicznych oraz przede wszystkim religijnych ${ }^{18}$. Tę samą opinię podziela także M. Dziekan przyznając, że same granice Iraku są tworem całkowicie sztucznym, wyznaczonym na początku XX w. przez Francuzów i Anglików. Natomiast mieszkańców tego kraju, poza sztucznymi granicami, praktycznie nic nie łączy ${ }^{19}$. Bez wątpienia mogła to być jedna z przyczyn późniejszych problemów religijnych Iraku.

Należy także dodać, iż do końca lat trzydziestych XX w. dominowała w Iraku przestarzała struktura społeczna, która miała charakter feudalny. Dominowała półkoczownicza hodowla bydła i prymitywne rolnictwo. Przeważająca część ludności mieszkała na wsi, tworząc różne wspólnoty plemienne i rodowe. Występowały tylko nieliczne ośrodki miejskie jak Bagdad i Mosul, które pełniły funkcje usługowo-administracyjne ${ }^{20}$.

Sytuacja zaczęła się zmieniać począwszy od lat pięćdziesiątych XX w. Kraj zaczął się szybciej rozwijać gospodarczo, a wszelkie problemy religijne były w rozmaity sposób thumione. Bez wątpienia ciężkim ciosem dla Iraku była prowadzona przez osiem lat wojna z Iranem w latach 1980-1988. Wówczas to kraj został w dużej mierze zrujnowany. Dodatkowo musiał zaciągnąc kredyty w Kuwejcie i Arabii Saudyjskiej na 40 mld dolarów. Kuwejt chciał darować Irakowi

\footnotetext{
${ }^{16}$ M. Z a w a d z k i: Nowy, wspaniaty Irak. Warszawa 2012 s. 11.

${ }^{17}$ J. L e 1 i w a: Irak wczoraj i dziś. Warszawa 1964 s. 54n.

${ }^{18}$ M. B r y l e w: Irak 2003-2005. Toruń 2011 s. 14n.

${ }^{19}$ M. D z i e k a n, dz. cyt., s. 249-253.

${ }^{20}$ J. G $\nmid$ o d e k, dz. cyt., s. 148.
} 
dhugi w zamian za uznanie jego granic. Jednak rządzący Irakiem Saddam Husajn nie zgodził się na takie rozwiązanie. Szerszy dostęp do Zatoki Perskiej dla państwa, które planowało szybki rozwój gospodarczy okazał się bardzo ważny. Wskutek tego, w sierpniu 1990 r., wojska irackie zajęły Kuwejt, który jednak z powodu międzynarodowej interwencji został w lutym $1991 \mathrm{r}$. wyzwolony ${ }^{21}$.

Szybki wzrost gospodarczy oraz ogromna chęć stworzenia z Iraku potęgi, zarówno gospodarczej jak i militarnej na Bliskim Wschodzie powodowały, że różnice religijne nie były tak bardzo istotne. Równocześnie uważano wówczas Irak za kraj, który posiada inne priorytety niż islam. Sytuacja była zasadniczo odmienna niż np. u południowych sąsiadów. To właśnie w Arabii Saudyjskiej podczas wspomnianej wojny w Zatoce Perskiej w 1991 r., gdy żołnierze Zachodu bronili tego kraju przed atakiem Saddama Husajna, nie było im wolno posiadać symboli religijnych, jak medaliki czy krzyżyki, a wojskowi kapelani nie mogli odprawiać nabożeństw. Nawet na pojazdach należących do Czerwonego Krzyża nie mógł widnieć tradycyjny emblemat tej organizacji. Pracujący w tym kraju przy wydobyciu ropy naftowej Filipińczycy, będący w większości katolikami, są poddani inwigilacji przez policję religijną. Nie wolno im świętować Bożego Narodzenia, ale są zobowiązani do przestrzegania ramadanu. Modlitwy organizowane w domach są często przyczyną aresztowann ${ }^{22}$. W tej sytuacji Irak, rządzony przez Saddama Husajna, wydawał się być niemal krajem świeckim.

Jednakże po obaleniu jego reżimu sytuacja się zmieniła. W Iraku zaczęło funkcjonować kilka partii politycznych, z których praktycznie większość ma związki z islamem. Najstarsza to Partia Propagandy Muzułmańskiej, następnie Organizacja Akcji Muzułmańskiej. Najmłodszą, ale i najliczniejszą jest Najwyższe Zgromadzenie Rewolucji Muzułmańskiej w Iraku ${ }^{23}$. W zasadzie już same nazwy wskazują na ich religijne nastawienie.

Równocześnie irackie Ministerstwo Zdrowia szacowało, że od 2003 r. do 2007 r., w czasie walk, zabitych zostało około 151 tys. Irakijczyków. Konsekwencją działań wojennych były także dewastacje dóbr kultury, a wiele cennych miejsc znanych z historii zostało zniszczonych. Do połowy 2008 r. swoje miejsce zamieszkania wewnątrz kraju zmieniło $2,8 \mathrm{mln}$ ludzi, natomiast ponad $2 \mathrm{mln}$ opuściło $\mathrm{Irak}^{24}$. Usunięcie reżimu doprowadziło do wybuchu walk pomiędzy szyitami i sunnitami oraz bardzo wieloma różnymi frakcjami, co spowodowało, że sytuacja stale się pogarszała.

${ }^{21}$ J. D a n e c k i: Konflikt Iracki. W: Oblicza wspótczesnego islamu. Red. E. M a c h u tM e n d e c k a. Warszawa 2003 s. 107.

${ }^{22}$ G. K u c h a r c z y k: Pod rządami pótksiężyca. Poznań 2006 s. 43-45.

${ }^{23}$ M. D z i e k a n, dz. cyt., s. 62-65.

${ }^{24}$ T. B r a ń k a, M. L or e n c, P. O s i e w i c z, A. P ot y r a $\nmid$ a: Irak. Między wojna a pokojem. Toruń 2010 s. 103-105. 
Można zatem dostrzec, że ukształtowane na początku XX w. w sztuczny sposób granice Iraku, mogły być przyczyną późniejszych napięć pomiędzy tamtejszymi religiami. Trudno jednoznacznie stwierdzić, że to różnice w wyznawanych religiach pomiędzy nacjami, które zajmowały Irak, były przyczyną rozlicznych wojen. Prawdopodobnie większe znaczenie miały indywidualne ambicje poszczególnych władców.

\section{Struktura religijna w Iraku}

Jak wcześniej wspomniano, po upadku reżimu Saddama Husajna nastąpiła w Iraku pewna eksplozja nastrojów religijnych. Dlatego też interesującą wydaje się próba ukazania struktury religijnej tego kraju. Nie zamierzamy jednak przedstawiać poszczególne frakcje wewnątrz grup religijnych, np. sunnitów czy szyitów, ani też zajmować się wymiarem politycznym tego zagadnienia. Pragniemy ukazać przede wszystkim wspomnianą strukturę ze szczególnym uwzględnieniem sytuacji chrześcijan, na którą wpływ ma pewna obyczajowość muzułmanów, co pozwala poznać lepiej przyczyny obecnej, jakże trudnej sytuacji w Iraku.

Już na początku należy zauważyć, że jak twierdzili niektórzy specjaliści zajmujący się problematyką Iraku, większość Irakijczyków na początku XXI wieku prezentowała umiarkowane przywiązanie do islamu jako religii ${ }^{25}$. Równocześnie trzeba przypomnieć inne dane, które mogły także wywrzeć wpływ na samą sytuację religijną w Iraku. W 2005 r. spośród irackich kobiet ponad 35\% było analfabetkami ${ }^{26}$, zaś w 2007 r. stopa bezrobocia wynosiła $60 \%$, a odsetek ludności żyjącej poniżej progu ubóstwa wynosił $34 \%{ }^{27}$. Były to bez wątpienia czynniki, które mogły doprowadzić do destabilizacji sytuacji w kraju.

Warto równocześnie zauważyć pewne zmiany, które nastąpiły w samym Iraku. W 1948 r. Irak był zamieszkiwany przez 4,8 mln ludności, jednak w 1977 roku liczba ta wzrosła do $12,2 \mathrm{mln}$ obywateli. Znaczący przyrost nastąpił jednak w kolejnych latach, co spowodowało, że w 2003 r. w Iraku żyło już 24,5 mln ludzi. Trzeba również zauważyć, że 77\% ludności stanowią Arabowie, $19 \%$ Kurdowie, natomiast pozostałe 4\% to Turkmeni, Ormianie, Asyryjczycy, Persowie, oraz niewielka ilość Żydów.

Należy także wspomnieć, iż zarówno An-Nadżaf jak i Karbala są świętymi miejscami szyizmu i ściągają corocznie rzesze pielgrzymów z całego świata ${ }^{28}$.

${ }^{25}$ A. P ł a c z e k, K. S t e f a n e k: Irak na początku XXI wieku. Łódź 2007 s. 111.

${ }^{26}$ A. Łu k a s z e w i c z: Afganistan i Irak: ekonomiczny bilans wojny z terroryzmem. Warszawa 2010 s. 47.

${ }^{27}$ Tamże, s.49.

${ }^{28}$ K. K o r z e n i e w s k i: Irak. Warszawa 2004, s. 110-117. 
Prawdopodobnie na sytuację w Iraku w znaczący sposób wpływa podział terytorialny kraju. Przykładem może być największa prowincja Al-Anbar, która w 1973 r. miała 138 tyś. km² powierzchni i liczyła 371 tys. mieszkańców, natomiast prowincja Babilon z powierzchnią 6,9 tyś. $\mathrm{km}^{2}$ liczyła wówczas 561 tyś. mieszkańców ${ }^{29}$. Nierównomierne rozmieszczenie ludności w kraju prowadzi do sytuacji, w której większe ośrodki miejskie oddziałują na prowincję, nie mając możliwości wypracowania własnego stanowiska. Równocześnie w kwestii religijnej można przyjąć, że opanowanie przez daną grupę religijną poszczególnych ośrodków miejskich ma kluczowe znaczenie.

Z kolei, co do samego nastawienia miejscowych chrześcijan do muzułmanów, to warto tu przytoczyć pogląd, znany na Bliskim Wschodzie od wieli wieków. Początkowo chrześcijanie nie postrzegali islamu jako religii, z którą będą musieli współegzystować. Przykład taki podawał w pewnym sensie św. Jan z Damaszku (zm. 750 r.) pochodzący z arabskiej, chrześcijańskiej rodziny, a wykształcony w duchu hellenistycznym, znający równocześnie islam oraz kulturę arabską. W dziele Pege gnoseos wymienił islam wśród 103 znanych wówczas herezji ${ }^{30}$. Równocześnie znane są również z historii przykłady zgodnego współżycia chrześcijan i muzułmanów. Istnieje korespondencja pomiędzy sułtanem An-Nasirem a papieżem Grzegorzem VII (zm. 1085 r.). W 1076 r. muzułmański władca skierował list do papieża, prosząc by wyświęcił on biskupa w celu sprawowania pieczy nad chrześcijanami pozostającymi pod jego władzą. Sułtan uwolnił wówczas chrześcijańskich niewolników oraz przesłał papieżowi dary. W odpowiedzi papież wysłał bardzo ciepły list, w którym pisał, że chrześcijanie i muzułmanie powinni żyć w zgodzie ${ }^{31}$.

To jednak bardziej, jak się wydaje, przeszłość niż współczesność. Obecnie ponad 95\% ludności dwudziestoczteromilionowego Iraku stanowią muzułmanie. $\mathrm{Z}$ kolei $54 \%$ z nich to szyici, a $34 \%$ to sunnici ${ }^{32}$.

Trzeba też pamiętać, iż szyizm po arabsku - sz-szi 'a, to nazwa nurtu religijnego i politycznego, obejmującego w islamie około $10 \%$ muzułmanów całego świata. To drugi, co do wielkości, po ortodoksyjnym sunnizmie odłam tej religii. Szyizm narodził się w VII w. po śmierci Mahometa, gdy nastąpił spór o inwestyturę, wynikający z braku wskazówek co do następstwa ze strony przywódcy wspólnoty ${ }^{33}$.

\footnotetext{
${ }^{29}$ GUS Departament Statystyki Międzynarodowej: Irak. Warszawa 1975 s. 8-10.

${ }^{30}$ E. S a k o w i c z: Historia dialogu chrześcijańsko-muzułmańskiego. W: Czy islam jest religia terrorystów? Red. E. S a k o w i c z. Kraków 2002 s. 129-134.

${ }^{31}$ Tamże, s. 129-134.

${ }^{32}$ M. K u b i a k, dz. cyt., s. $157 \mathrm{n}$.

${ }^{33}$ M. D z i e k a n, dz. cyt., s. 43.
} 
Mając to wszystko na uwadze M. Brylew ${ }^{34}$ twierdzi, że do przyczyn destabilizacji sytuacji w Iraku można zaliczyć głęboko zakorzenione w społeczeństwie podziały religijne i etniczne. Przy tym, dążenie poszczególnych ugrupowań religijnych do przejęcia władzy i zbudowania państwa o charakterze religijnym, miało tu istotne znaczenie. Po upadku Saddama Husajna trzy największe grupy religijne, tj. arabscy sunnici, arabscy szyici oraz Kurdowie zdominowali scenę polityczną.

Warto tu przypomnieć, że w latach 1920-1930, gdy kształtowało się młode państwo irackie, większość urzędów sprawowana była przez sunnitów. Dominacja sunnitów trwała do 1958 r., jednak i później niewiele się zmieniło. Natomiast po dojściu do władzy partii Baas, rola sunnitów wzrosła na ponad trzy dekady.

Z kolei powstała w 2003 r. Armia Mahdiego ${ }^{35}$, skierowała swoje działania przeciw chrześcijanom, którzy naruszali surowe normy islamu ${ }^{36}$. Trzeba też zaznaczyć, że w 1973 r. iraccy chrześcijanie stanowili 2,6 \% ludności, natomiast w 2006 r. tylko $1 \%$. Ta dysproporcja powoduje naturalne problemy społeczności chrześcijańskiej, która częściej woli nie angażować się w życie kraju, aby następnie nie być posądzoną za stronniczkę, którejś ze stron konfliktu.

Informacje o ogromnych problemach chrześcijan potwierdził łaciński arcybiskup Bagdadu Jean Benjamin Sleiman. Przyznał on, że relacje z islamem należą do najtrudniejszych kwestii, z którymi muszą się zmierzyć chrześcijanie na tym terenie ${ }^{37}$. Ukazuje to niejako obraz z kwietnia 2003 r., kiedy to podczas pielgrzymki do świętego miasta Karbali, tysiące irackich szyitów wznosiło okrzyki: Nie Ameryce. Nie Saddamowi. Tak-dla islamu! ${ }^{38}$.

Jednakże trzeba też zaznaczyć, iż władze państw arabskich w obliczu sytuacji w Iraku obawiały się od wielu lat bardziej eskalacji konfliktu szyickosunnickiego, niż konfliktu z chrześcijanami. Warto przypomnieć, że według niektórych danych, w Iraku nawet ok. 60-65\% muzułmanów to szyici, którzy byli dyskryminowani za czasów Saddama Husajna - sunnity. Równocześnie w państwach regionu żyją znaczne mniejszości szyickie, które uważają się za niereprezentowane we władzach, czy pozbawione gospodarczych i społecznych możliwości rozwoju. Można tu wskazać Arabię Saudyjską, w której tylko 15\% społeczności stanowią szyici. Dlatego też pojawiały się głosy polityków i religijnych przywódców, wzywające do udzielenia politycznego wsparcia arabskiej społeczności sunnitów w Iraku i niedopuszczenia do szyickiej dominacji w regionie.

\footnotetext{
${ }^{34}$ Adiunkt katedry Bezpieczeństwa Narodowego Akademii Pomorskiej w Słupsku, brał udział w misjach pokojowych w Libanie.

${ }^{35}$ Milicja wspierająca działania Mutady w liczbie około 20 tyś.

${ }^{36}$ M. B r y l e w, dz. cyt., s. 190-199.

${ }^{37} \mathrm{P}$. S i n i s c a l c o, dz. cyt., s. 16 n.

${ }^{38}$ M. K u b i a k, dz. cyt., s. 157.
} 
W pewnym sensie podobna sytuacja występuje w Kuwejcie, gdzie ok. 30\% muzułmanów to szyici. Sytuację dodatkowo komplikuje fakt, że szyickie mniejszości w tych państwach zamieszkują tereny bogate w ropę naftową. Problem ten dostrzegają również inne państwa. W 2007 r. podczas spotkania delegacji Stanów Zjednoczonych i Iranu ten ostatni zobowiązał się, m.in. pomóc młodej irackiej administracji w stosunkach z szyicką większością oraz zwiększyć bezpieczeństwo na granicy irańsko-irackiej ${ }^{39}$.

Problem szyicko-sunnicki w Iraku niej jest jednak problemem całkowicie nowym. Co prawda, jak to już przedstawiono, przed obaleniem reżimu nie był on tak widoczny, jednak, np. zarówno w 1979 r. jak i 1980 r. prześladowano bardzo szyitów w Iraku. Ich przywódca ajatollah Muhammad Bakr as-Sadr został wówczas zamordowany w czasie śledztwa. Irak oskarżał wówczas Iran o to, że chce przenieść rewolucję islamską do Iraku ${ }^{40}$.

Problemy szyicko-sunnickie to oczywiście tylko część sytuacji religijnej Iraku, na którą nakładają się niejako relacje do chrześcijaństwa. Aby właściwie rozumieć pewne pojęcia oraz nie traktować wszystkich muzułmanów z Iraku jako fundamentalistów, należy zapewne przyjrzeć się pojęciu dżihad, które często wymieniane jest w mediach. Jak twierdzi K. Korzeniewski, słowo dżihad w kulturze zachodniej jest często błędnie interpretowane jako święta wojna $\mathrm{z}$ niewiernymi, tymczasem pierwotnie oznacza ono doktadanie starań $i$ wysitków $w$ dążeniu do jakiegoś celu. Celem tym jest szerzenie i obrona islamu ${ }^{41}$. Równocześnie trzeba przyznać, iż prawo muzułmańskie wyodrębniło cztery sposoby prowadzenia dżihadu: sercem, językiem, rękami i mieczem. Celem dżihadu jest każde działanie czy przedsięwzięcie mające na celu krzewienie islamu i budowanie chwały muzułmańskiej religii. Tym samym muzułmanin, który prowadzi dżihad sercem (hadisy określają to mianem dżihadu większego), to człowiek walczący ze złem gnieżdżącym się $w$ jego duszy i podszeptami szatana oraz starający się trwać w swojej wierze. Z kolei muzułmanin, który działa językiem i rękami, to człowiek zapobiegający szkodom wyrządzonym gminie muzułmańskiej lub naprawiający takie szkody. Dopiero prowadzenie dżihadu mieczem (kital) odpowiada zachodniej definicji wojny religijnej. Koran w dużej mierze wzywa jednak tylko do kitalu w wypadku odpierania ataku. Trzeba również pamiętać o historycznym kontekście powstania Koranu. Islam był wtedy bardzo dynamicznie rozwijającą się religią i oprócz spraw czysto duchowych, religijnych i moralnych musiał także regulować życie społeczne i polityczne młodej powstającej państwowości. Prowadziło to do sytuacji, w której terminy dżihad i kital często były używane wymiennie. Jednakże w XX w. idea dżihadu nabrała nowego wymiaru. Powstali wówczas fundamentaliści islamscy, którzy

\footnotetext{
${ }^{39}$ T. B rańk a, M. Loren c, P. O s i e w i c z, A. P o t y r a ła, dz. cyt., s. $124 n$.

${ }^{40}$ J. B i z i e w s k i: Irak-Iran 80-88. Warszawa 1993 s. 5n.

${ }^{41}$ K. K o r z e n i e w s k i, dz. cyt., s. 85.
} 
uznają przez to zbrojne przeciwstawienie się wszelkim przejawom cywilizacji zachodniej $^{42}$.

Z drugiej jednak strony należy zauważyć, że dla muzułmanina ogromne znaczeniem ma charakter człowieka, jego godność, honor, reputacja. Nie szczędzi się wysiłków w ich obronie. Hańba jednego człowieka przenosi się na całą rodzinę. Lojalność i obowiązki wobec rodziny są ważniejsze niż lojalność wobec przyjaciół, pracodawców. Krewni muszą sobie nawzajem pomagać, w razie potrzeby także finansowo.

Przynależność do rodziny daje poczucie bezpieczeństwa i pewność, że dana osoba nigdy nie pozostanie bez środków do życia, ani też nie będzie pozbawiona psychicznego wsparcia ${ }^{43}$. Są to zasady powszechne na terenie Bliskiego Wschodu, które nie powinny jednak psuć relacji chrześcijańsko-muzułmańskich. Trzeba jednak przyznać, iż muzułmanie zacieśniają swe kontakty do rodziny, czyli tylko do muzułmanów, nie są w stanie pozyskać właściwego obrazu ludzi należących do innych religii. To, co o nich wiedzą, wynika głównie z tego, co jest im przekazane przez innych muzułmanów. Sytuacja taka ma często miejsce mimo, że zarówno chrześcijanie, jak i muzułmanie niejednokrotnie żyją obok siebie.

Dla jeszcze większej przynależności do danej grupy, rodziny, generalnie rodziny muzułmańskiej, w islamie już od czwartego roku życia dzieci rozpoczynają naukę w specjalnej szkole koranicznej. Natomiast od dwunastego roku życia wprowadza się je w praktyki postu. Najpierw jest to post jednodniowy, w następnym roku dwudniowy itd., aż do osiągnięcia dojrzałości. Natomiast przeciętny pobożny Irakijczyk, kiedy ma rozpocząć jakąś pracę, to przedtem recytuje zdanie z Koranu: W imię Allaha, bogatego w milosierdzie i wielce taskawego. Muzułmanin taki kończy z kolei swoją pracę słowami: Chwała niech będzie Allahowi. Kiedy muzułmanin czyni komuś jakąś obietnicę, to często dodaje Insz' Allah, co odpowiada polskiemu, jeśli Bóg da. Czasami bywa to również bardzo wyrafinowana forma odmowy ${ }^{44}$.

Dlatego też w wielu krajach, w których islam stanowi główną religię, a do których chce zapewne zaliczać się Państwo Islamskie, rozgraniczenie między prawem cywilnym, a tym które opiera się na Koranie, jest bardzo niewyraźne. W niektórych wypadkach władze państwowe, często pod naciskiem integrystycznych grup islamu, usiłują narzucić jednakowe dla wszystkich obywateli prawo, wywodzące się właśnie z Koranu. Oczywiście, takie postępowanie sprzeciwia się prawu do wolności religijnej w ujęciu chrześcijańskim ${ }^{45}$.

\footnotetext{
${ }^{42}$ Tamże, s. $85 \mathrm{n}$.

${ }^{43}$ Tamże, s. 92

${ }^{44}$ A. W o 1 a n i n: Dialog chrześcijaństwa z innymi religiami. Kraków 1993 s. 78-81.

${ }^{45}$ Tamże, s. 73n.
} 
Trzeba jeszcze dodać, iż szyici i sunnici, o których zostało już sporo napisane, to jednak nie całość irackiej mozaiki religijnej. Istotną jej część stanowią Ormianie - chrześcijanie, którzy stanowią około 0,6 populacji kraju. Mieszkają oni głównie w Bagdadzie i innych dużych miastach. Są potomkami tych Ormian, którzy w 1915 r. uciekali przed pogromem w imperium Osmańskim. W większości są oni dwujęzyczni, posługują się arabskim i ormiańskim.

Kolejną grupę chrześcijan w Iraku stanowią Asyryjczycy. Zamieszkują oni Irak od ponad 3 tysięcy lat. Uważani są za potomków ludności tubylczej. Stanowią $1 \%$ ludności kraju i zamieszkują jego północne tereny. Używają języka nowoaramejskiego. Są wyznawcami Asyryjskiego Kościoła Wschodu. Uważają się za odrębny naród. W przeszłości współpracowali z Anglikami w thumieniu arabskich powstań, co do dzisiaj pamiętają im w kraju.

Trzeba tu zaznaczyć, iż językiem urzędowym w Iraku jest arabski, co powoduje, że większość chrześcijan jest dwujęzyczna. Jednakże na terenach Kurdyjskiego Okręgu Autonomicznego językiem urzędowym jest także kurdyjski.

W zasadzie na co dzień Irakijczycy posługują się własnym dialektem języka arabskiego. Natomiast największy odłam chrześcijański w Iraku stanowią Chaldejczycy, których liczba - jak się ocenia - wynosi około 450 tysięcy wyznawców. Mają oni swojego patriarchę w Bagdadzie.

Natomiast obecni na terenie Iraku jakobici przybyli na te tereny z Syrii, uciekając przed prześladowaniami.

Istnieje na tych terenach także sekta jazydów, która została założona w XII wieku. Religia ta wywodzi się z islamu, wchłonęła jednak z czasem elementy chrześcijaństwa oraz dawnych religii z tego terenu. Z kolei sabejczycy, skupiają się w Bagdadzie i na obszarze rozlewisk na południu kraju. Liczbę ich wyznawców szacuje się na około 20 tys. Za swojego proroka uważają Jana Chrzciciela ${ }^{46}$.

Trzeba także zauważyć, że w samej tylko prowincji Kirkuk stanowiący mniejszość Asyryjczycy, Chaldejczycy, Ormianie, czyli licząca około 12 tysięcy społeczność chrześcijańska, nie stanowiła siły, która mogłaby wysuwać jakiekolwiek żądania. W przeszłości Asyryjczycy byli prześladowani zarówno przez Kurdów jak i Arabów. Asyryjczycy podczas konfliktów po obaleniu reżimu Saddama Husajna starali się utrzymywać z daleka od narastającego konfliktu, przypuszczając, że zapewne prędzej czy później staną się jego ofiarą ${ }^{47}$.

Interesującym może się wydawać fakt, że sytuację w Iraku mieszkańcy oceniają w zależności od tego, do jakiej grupy wyznaniowej należą. I tak sunnici

\footnotetext{
${ }^{46}$ K. Kor z e n i e w s k i, dz. cyt., s. $110-117$.

${ }^{47}$ M. B r y l e w, dz. cyt., s. 206n.
} 
oceniali sytuację w kraju w 2009 r. tylko w 8\% jako bardzo dobrą, natomiast szyici aż w $25 \%$, a Kurdowie w $32 \%$.

Jak można było zatem zauważyć, złożona mozaika religijna wcale nie musiałaby stać się przyczyną konfliktów w Iraku. Poznanie pewnych zasad życia muzułmanów pozwala to zdanie podtrzymać. Być może jedynie pewna niejednoznaczność Koranu co do istotnych terminów, np. dżihadu, powoduje, że są one negatywnie interpretowane w niektórych kręgach irackich muzułmanów.

\section{Kościoły w Iraku}

Złożona sytuacja religijna w Iraku, bez wątpienia, wymaga wielkiego heroizmu od tamtejszych chrześcijan. W pierwszym punkcie niniejszego artykułu zostały już wskazane przyczyny pojawienia się chrześcijan na tym terenie. Powstaje zatem pytanie, czy istnienie chrześcijan w tym kraju mogło być przyczyną konfliktów zbrojnych, szczególnie ostatniego związanego z powstaniem Państwa Islamskiego? Chcąc odpowiedzieć na to pytanie należałoby zapewne przyjrzeć się historii Kościołów, które często od wieków znajdują się w Iraku.

Niewątpliwie najliczniejszy na terenie Iraku jest Chaldejski Kościół katolicki. Katolicy obrządku chaldejskiego są potomkami nestorian, którzy na przestrzeni wieków wracali do jedności z Rzymem ${ }^{49}$. Trzeba tu zaznaczyć, że już w połowie XVI w. patriarcha Kościoła chaldejskiego, Jan Szymon Sulaka, został uznany przez Rzym jako patriarcha Chaldejczyków. Natomiast w 1830 r. metropolita miasta Mosul został uznany przez papieża Piusa VIII i otrzymał tytuł patriarchy chaldejskiej Babilonii ${ }^{50}$. Równocześnie M. Banaszak pisze, że patriarcha nestorian w Persji i Kurdystanie, Symeon VI, złożył katolickie wyznanie wiary w 1771 r. i uznał prymat papieski. Zaznacza jednak, że było to odnowienie unii, którą porzucono przed laty. Autor ten przyznaje także, że po znacznych zawirowaniach co do trwałości unii w 1841 r., unicki patriarcha Mar Hanna przeniósł swą stolicę do Bagdadu ${ }^{51}$. Faktem jest również, że w ciągu wieków siedziba chaldejskiego patriarchatu była wielokrotnie zmieniana. R. Roberson podaje, że w 1830 r. została przeniesiona do Mosulu, aby w 1850 r. ostatecznie zostać ustanowiona w Bagdadzie. Począwszy od XIX w. ich patriarcha nosił tytuł patriarchy Babilonu i Chaldejczyków ${ }^{52}$. Jak podawał R. Dąbrowski, w Iraku

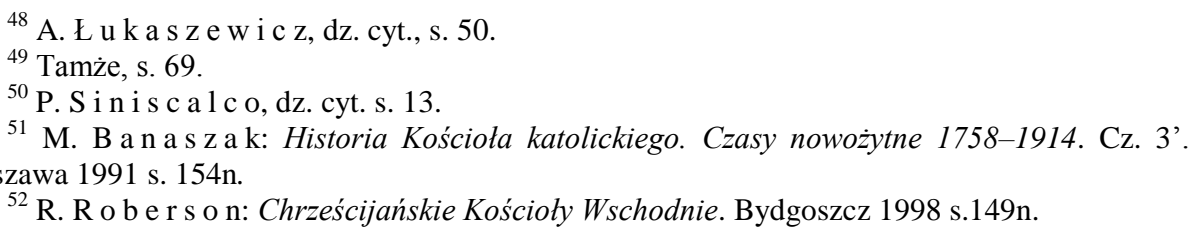


wiernych Chaldejczyków było w połowie XX w. około 145 tys. W swoim obrządku używają dawnego języka chaldejskiego. W związku z tym, że jest on jednak niezrozumiały dla ludu, Pismo św. oraz formuły liturgiczne odczytują po $\operatorname{arabsku}^{53}$. Istotną rolę $\mathrm{w}$ tym Kościele na terenie Iraku odgrywa patriarchalne seminarium św. Piotra w Bagdadzie. Natomiast jeszcze do niedawna, zarówno w Bagdadzie jak i w Mosulu, mieściły się ośrodki oferujące kursy teologiczne. Potwierdza to wyraźnie, że w czasach reżimu Saddama Husajna istniała względna tolerancja religijna w stosunku do chrześcijan. W okresie tym znajdowało się w Iraku dziesięć diecezji chaldejskich. Natomiast liczba wiernych tego Kościoła w latach dziewięćdziesiątych XX w. była określana na około 313 tys. Ich namiestnik, który został wybrany w 1989 r., nazywał się wówczas patriarcha Raphael I BiDawid ${ }^{54}$.

Trzeba tu zaznaczyć, że informacje o tym, iż od 1830 r. istnieje Katolicki Patriarchat Chaldejski Babilonii z siedzibą w Bagdadzie, potwierdza również E. Przekop ${ }^{55}$. Po latach sytuacja tego Kościoła uległa znacznemu pogorszeniu, co doprowadziło do tego, że unitów chaldejskich nie było fizycznie w trzech istniejących formalnie diecezjach chaldejskich ${ }^{56}$.

Natomiast o tym jak do niedawna, czyli jeszcze w czasach względnej tolerancji, traktowane były świątynie chrześcijańskie w Iraku może świadczyć fakt, iż w samym Bagdadzie targ korzenny, znajdujący się na głównej ulicy Ar-Raszid sięgał aż do kościoła Chaldejczyków ${ }^{57}$.

Z kolei Kościołem, od którego odłączyli się Chaldejczycy jest Asyryjski Kościół Wschodu. Otóż Kościół nestoriański, bo tak bywa najczęściej nazywany, rozwinął się początkowo w Mezopotamii, Chaldei i Kurdystanie ${ }^{58}$. W V wieku skłaniał się on ku chrystologii zaproponowanej przez Teodora z Mopsuestii i Nestoriusza. W związku z tym stracił łączność z Kościołem w Cesarstwie Rzymskim. Wierni tego Kościoła wygnani przez cesarza Zeno (474-491), osiedlili się w Persji, oddalając się od oficjalnego Kościoła, aby w samej Persji nie być posądzanym o kolaborację z Rzymianami. Ważnym faktem z jego dziejów jest to, iż przez cały czas prowadził bardzo ożywioną działalność misyjną. Trzeba także zaznaczyć, że w V w. synod tego Kościoła zarządził, iż celibat w tym Kościele, nie wyłączając biskupów, nie będzie obowiązkowy. Z kolei w VI wie-

${ }^{53}$ R. D ą b ro w s k i: Osobliwości w Kościołach Wschodnich. Lublin 1960 s. 70.

${ }^{54}$ R. R o b e r s o n, dz. cyt., s. 149 n.

${ }^{55}$ E. Prze k o p: Pozycja prawna patriarchy Wschodniego Kościoła katolickiego. Lublin 1976 s. 37.

${ }^{56}$ M. B a n a s z a k: Historia Kościoła katolickiego. Czasy najnowsze 1914-1978. Cz. 4. Warszawa 1992 s. 91-93.

${ }^{57}$ B. W r on a: Od Bagdadu do Marrakeszu: wędrówki po krajach arabskich. W: Oblicza wspótczesnego islamu. Red. E. M a c h u t-M e n d e c k a. Warszawa 2003 s. 178n.

${ }^{58}$ R. D ą b r o w s k i, dz. cyt., s. 52. 
ku powzięto jednak decyzję, o wyświęcaniu biskupów tylko spośród mnichów żyjących w celibacie. Natomiast księżom zawsze było wolno zawierać związki małżeńskie, nawet po przyjęciu święceń. Należy także zauważyć, że Kościół ten rozwijał się wokół szkoły nisbijskiej. Równocześnie prowadzona przez niego działalność misyjna zaprowadziła chrześcijaństwo do Indii, Tybetu, Chin i Mongolii. W zasadzie, nawet podbój przez muzułmańskich Arabów w VI w., nie powstrzymał ich działalności misyjnej ${ }^{59}$. Bardzo dobre relacje nestorian z Mongołami, jak twierdzi P. Siniscalco, mogły zaowocować porozumieniem tych drugich z państwami łacińskimi z Ziemi Świętej. Niestety, błędna polityka krzyżowców doprowadziła do tego, że Mongołowie zostali pokonani przez Mameluków z Egiptu w 1260 r. i zepchnięci do Mezopotamii ${ }^{60}$. Istotnym w dziejach nestorian było także to, że za panowania dynastii Tang w Chinach wielu Chińczyków w latach 618-907 właśnie od nich przyjęło chrześcijaństwo. W $781 \mathrm{r}$. wzniesiono w stolicy ówczesnych Chin, Sianfu, wielki pomnik z opisem dziejów Kościoła w Chinach. Co prawda okresy tolerancji w tym kraju przeplatały się z okresami braku tolerancji, jednak w 1275 r. utworzono w Pekinie arcybiskupstwo, a w innych miastach zbudowano dwa kościoły ${ }^{61}$. Wszystko to było bez wątpienia zasługą nestorian z terenu obecnego Iraku.

Niestety, pod koniec XIV w. podczas inwazji Tamerlana, chrześcijanie ci zostali niemal całkowicie wyniszczeni. Dodatkowym osłabieniem tego Kościoła było utworzenie wspomnianego jego katolickiego odłamu.

Podczas I wojny światowej Asyryjczycy byli licznie deportowani. Turcy dokonywali na nich masakr, ponieważ podejrzewali ich o popieranie angielskiego wroga. Równocześnie ci, którzy przetrwali, uciekli na południe Iraku w nadziei, że Wielka Brytania będzie ich ochraniać. Jednak, po wygaśnięciu brytyjskiego mandatu na tych terenach w 1933 r., miała miejsce kolejna ich rzeź. Władze irackie pozbawiły Mar Simona - patriarchę asyryjskiego, obywatelstwa i wygnały go z kraju. Udał się on na wygnanie do San Francisco.

Następne lata w Kościele Asyryjskim to okres pewnego chaosu, związanego z sukcesją patriarchalną. Dopiero w 1976 r., z wyborem Mar Dinkha IV spory, sukcesyjne zostały zakończone ${ }^{62}$.

P. Siniscalco podaje, że Kościół, ten ma dwóch patriarchów, w Bagdadzie rezyduje Mar Addai, któremu podlega około 50 tys. wiernych, natomiast w Chicago - Mar Dinkha IV, któremu podlega 250. tysięczna diaspora ${ }^{63}$.W połowie lat

\footnotetext{
${ }^{59}$ R. R o b e r s o n, dz. cyt., s. 25-28.

${ }^{60} \mathrm{P}$. S i n i s c a 1 c o, dz. cyt., s. 208.

${ }^{61}$ N. Z e r n o v, dz. cyt., s. $97 \mathrm{n}$.

${ }^{62}$ R. R o b e r s o n, dz. cyt., s. 25-28.

${ }^{63} \mathrm{P}$. S i n i s c a l c o, dz. cyt., s. 11 n.
} 
dziewięćdziesiątych XX w. liczba Asyryjczyków na świecie szacowana była na około 400 tys. ${ }^{64}$.

Należy też wspomnieć, iż w 1970 r. wydawało się, że sytuacja chrześcijan w Iraku będzie coraz lepsza. Władze doszły wówczas do porozumienia z nestorianami. Oddano im wówczas zabrane i zniszczone w ciągu ostatnich pięciu lat kościoły. Wówczas podniosły się głosy domagające się powrotu do ojczyzny lub rezygnacji patriarchy Mar Szymona XXI Eszi. Ostatecznie zrezygnował on jednak z urzędu. W 1978 r. odbył się w Bagdadzie synod Kościoła nestoriańskiego, który m.in. miał na celu zakończenie pewnej jego wewnętrznej schizmy ${ }^{65}$.

Niektóre z tych informacji potwierdza także B. Kumor, który przyznaje, że bardzo trudne były losy nestorian po I wojnie światowej. Przypomina, że po powrocie z Anglii patriarchy Mar Szymona XXI Eszi (1920-1973), nestorianie podjęli walkę o niepodległość. Zostali jednak pokonani przez Arabów. Doprowadziło to do sytuacji, w której w 1933 r. patriarcha musiał zrezygnować z władzy cywilnej. Natomiast w 1973 r. libański synod nestoriański przyjął całkowitą rezygnację wspomnianego patriarchy, który praktycznie od 1940 r. przybywał w Stanach Zjednoczonych ${ }^{66}$. Na początku XX wieku Kościół Asyryjski obejmował 8 metropolii i kilka biskupstw podporządkowanych władzy katolikosa (patriarchy).

Trzeba też zauważyć, iż wskutek przejść do Kościoła anglikańskiego oraz prawosławnego rosyjskiego oraz krwawych prześladowań ze strony Kurdów liczba wiernych stale malała ${ }^{67}$.

Innym ważnym Kościołem na terenie Iraku jest Kościół jakobicki. Nazywany Syryjskim Kościołem Prawosławnym, został nazwany jakobickim od Jakuba Baradai, biskupa Edessy, który w VI w. popierał tych, którzy odrzucili postanowienia z Chalcedonu. R. Roberson podaje, że obecnie Kościół ten liczy około 250 tys. wiernych ${ }^{68}$. Potwierdza to również R. Dąbrowski pisząc, że Kościół jakobicki taką nazwę otrzymał od Jakuba Baradeusza, który w połowie VI wieku zjednoczył monofizytów w Syrii. Z wdzięczności za jego trzydziestotrzyletnie trudy monofizyci syryjscy przyjęli nazwę jakobitów ${ }^{69}$.

W czasach współczesnych, na skutek krwawych walk pomiędzy Kurdami a nestorianami, patriarcha tego Kościoła w 1932 r. przeniósł rezydencję patriar-

\footnotetext{
${ }^{64}$ R. R o b e r s o n, dz. cyt., s. 28.

${ }^{65}$ B. K u m o r: Historia Kościoła. Cz. 8. Lublin 1996 s. 594n.

${ }^{66}$ Tamże.

${ }^{67}$ B. K u m o r: Historia Kościoła. Cz. 7. Lublin 1991 s. 447.

${ }^{68}$ R. R o b e r s o n, dz. cyt., s. 43-45.

${ }^{69}$ R. D ą b r o w s k i, dz. cyt., s. 39.
} 
chatu do Homs w Iraku. Z kolei w 1969 r. Ignacy Zakka I Iwas został wybrany arcybiskupem Mosulu ${ }^{70}$.

Na terenie Iraku znajdują się także wierni Syryjskiego Kościoła katolickiego. Używają oni głównie języka arabskiego. Natomiast język syryjski używany jest tylko w niektórych wioskach w północnym Iraku ${ }^{71}$. Trzeba zauważyć, że to w XVII w. za sprawą łacińskich misjonarzy, część wiernych Kościoła syryjskiego zbliżyła się do Rzymu. W 1662 r. w czasach patriarchy Ignacego Andrzeja Akhidjana, Kościół zaczął określać się mianem Syryjskiego Kościoła katolickiego, jednak dopiero w latach 1782-1783 zawarł definitywnie unię z Rzymem. Obecnie liczy około 175 tys. wiernych.

Na przestrzeni wieków Kościół jakobicki - unicki (syryjski) nie miał wielu wyznawców, w 1840 r. liczył około 30 tys. członków. Przyczyną tego stanu rzeczy było prawdopodobnie zatwierdzenie przez papieża dopiero $\mathrm{w} 1828 \mathrm{r}$. patriarchy, którego uznał sułtan. Patriarcha ten przeniósł wówczas swą stolicę do Aleppo $^{72}$. Natomiast po I wojnie światowej patriarcha Kościoła jakobickiego unickiego, Ignacy Efrem II Rachmani, wydał jednolite księgi liturgiczne oraz przeniósł swoją siedzibę do Bejrutu. Jak pisze G. Kucharczyk, znaczne prześladowania Kościoła jakobickiego unickiego na początku I wojny światowej przez muzułmańskich Turków, doprowadziły do masowej fali emigracji wyznawców ${ }^{73}$.

Informacje te potwierdza również M. Banaszak uznając, iż trudna sytuacja Turcji po I wojnie światowej spowodowała, że unicki patriarcha syryjski przeniósł swą stolicę z Mardin do Bejrutu ${ }^{74}$.

Kościołem posiadającym ogromne tradycje na terenie Iraku jest Ormiański Kościół katolicki. W ostatnim czasie posiadał on jedną diecezję na terenie Ira$\mathrm{ku}^{75}$. Kościół ten ogranicza się tylko do Ormian katolików i ich ormiańskiego obrządku. Są oni potomkami tych Ormian monofizytów, którzy już od XII wieku w pewnych odstępach czasu jednoczyli się z Rzymem. Co prawda w 1198 roku uroczyście ogłosili oni unię kościelną, jednak spotykała się ona z wielokrotnym zaprzeczeniem ${ }^{76}$. Dlatego też często uznaje się, że dopiero w 1740 r. powstało katolickie odgałęzienie Kościoła ormiańskiego ${ }^{77}$.

\footnotetext{
${ }^{70}$ B. K u m o r: Historia Kościoła. Cz. 8, dz. cyt., s. 590n.

${ }^{71}$ R. R o b e r s o n, dz. cyt., s.161.

${ }^{72}$ M. B a n a s z a k: Historia Kościoła katolickiego. Cz.3', dz. cyt., s. $154 \mathrm{n}$.

${ }^{73} \mathrm{G}$. K u c h a r c z y k, dz. cyt., s. 63-65.

${ }^{74}$ M. B a n a s z a k: Historia Kościoła katolickiego. Cz. 4, dz. cyt., s. 91-93.

${ }^{75}$ R. R o be r s o n, dz. cyt., s. 155.

${ }^{76}$ R. D ą b r o w s k i, dz. cyt., s. 66

${ }^{77}$ P. S i n i s c a l c o, dz. cyt., s. 14.
} 
Trzeba tu zaznaczyć, iż wspomniany Kościół jest pewnym odłamem Ormiańskiego Kościoła Apostolskiego, który w 506 r. odrzucił chrystologiczne nauki Soboru Chalcedońskiego ${ }^{78}$.

Z kolei Ormiański Kościół monofizycki zachowuje obecnie obrządek sobie tylko właściwy i posługuje się $\mathrm{w}$ nim językiem staroormiańskim ${ }^{79}$. Na początku $\mathrm{XX}$ w. jego członkowie doświadczyli wielu masakr ze strony Turków. Obecnie Kościół ten liczy ok. 6 mil wiernych ${ }^{80}$.

Traktując wszystkie te Kościoły jako chrześcijan z Iraku trzeba zauważyć, iż obecnie stanowią oni około $3 \%$ z 25. milionowej ludności Iraku. Od czasów II wojny w Zatoce w 2003 r., iraccy chrześcijanie stali się obiektem seryjnych ataków ze strony rosnących w siłę fundamentalistów islamskich. Znane są ataki na kościoły w 2004 r. w Bagdadzie i Mosulu. Chrześcijanie są tam często porywani dla okupu. Niestety, często zdarzają się sytuacje, że porwany człowiek jest zabijany, jeśli rodzina nie jest $\mathrm{w}$ stanie zapłacić okupu ${ }^{81}$.

\section{Przezwyciężyć chęć dominacji}

Kościoły z terenu obecnego Iraku znajdowały się przez wieki w wielkim paśmie cierpień i prześladowań. Podobnie było w XX w. Ich wyciszenie w ostatnim dziesięcioleciu miało na celu uniknięcie zarzutu mieszania się do aktualnej sytuacji politycznej kraju.

Jeszcze przez ostatecznym obaleniem reżimu Saddama Husajna, praktycznie już w lutym 2003 r., rozpoczęła się kolejna pokojowa ofensywa Jana Pawła II w sprawie Iraku. Papież spotkał się wówczas z sześcioma ważnymi wtedy politykami, m.in. z T. Blairem, T. Azisem, K. Annanem oraz przedstawicielem szefa teokratycznej Republiki Iranu. Równocześnie 15 lutego tego roku do Bagdadu udał się papieski wysłannik, kard. Roger Etchagaray oraz kard. Pio Laghi, który przybył tam ponownie w kolejnym miesiącu. Chciano uniknąć wojny i cierpienia ludności irackiej. Bez wątpienia linia dyplomacji Jana Pawła II miała na celu uniknięcie podziałów dyplomatycznych i wspieranie ONZ. Stolica Apostolska potwierdziła, że wojna prewencyjna nie jest stuszna wojna. Papież podkreślał, iż zastosowanie siły pozostaje ostatecznym wyjściem. Równocześnie przyznano, że nie wolno pragnąć pokoju za wszelką cenę. Stolica Apostolska przypomniała, że nie propaguje pacyfizmu, lecz pokój.

\footnotetext{
${ }^{78}$ R. R o b e r s o n, dz. cyt., s. $34-37$.

${ }^{79}$ R. D ą b r o w s k i, dz. cyt., s. 33-39.

${ }^{80}$ R. R o b e r s o n, dz. cyt., s. $34-37$.

${ }^{81}$ Tamże, s.74-76.
} 
Niestety papież nie posiadał takiej siły politycznej, która zmusiłaby innych do respektowania jego woli. Uczyniwszy wszystko, co było możliwe, Jan Paweł II ogłosił dzień 5 marca 2003 r. dniem modlitwy i postu o pokój na Bliskim Wschodzie. Papież powiedział także, że Oczywiście na politykach z Bagdadu spoczywa obowiqzek petnej wspótpracy ze wspólnota międzynarodowa, by wyeliminować wszystkie powody do interwencji zbrojnej. Do nich zwracam się z usilnym apelem: niech zawsze troszczq się przede wszystkim o losy swoich wspótobywateli ${ }^{82}$.

Apele papieża nie odniosły oczekiwanych rezultatów. Jednak znacznie gorzej było z apelami, które wygłaszali przywódcy niektórych państw w sprawie Iraku. Otóż w 1991 r. podczas operacji Pustynna Burza prezydent Stanów Zjednoczonych Ameryki, George Bush zaapelował do Kurdów z północy Iraku, aby wystąpili przeciwko Husajnowi. Równocześnie wzywał do tego samego szyitów z południa Iraku. Na skutek tych apeli każda z tych nacji wznieciła powstania niepodległościowe. Gdy jednak zakończyła się amerykańska operacja, wojska irackie zostały przerzucone na północ do ostatecznego zakończenia sprawy kurdyjskiej. Wówczas wielkie rzesze Kurdów uciekły do Turcji oraz Iranu. Natomiast na południu tłumienie powstania szyickiego trwało aż do $1993 \mathrm{r}$ Kampania przeciw szyitom zakończyła się zabiciem około 100 tys. osób ${ }^{83}$. Można z tego jasno wywnioskować, że przemocą nie rozwiąże się problemów religijnych w Iraku.

Przedstawiona wcześniej historia Iraku wskazała, że nie tyle poszczególne religie ponoszą odpowiedzialność za sytuację w Iraku, ile samo stworzenie w bardzo sztuczny sposób państwa, którego obywateli niewiele łączy. Do podobnego wniosku można było dojść po lekturze kolejnego rozdziału, który ukazał, że nie można winić przeciętnego muzułmanina za obecną sytuację Iraku. Być może pewne niejednoznaczności Koranu odnośnie do takich terminów jak np. dżihad, powodują pewne reakcje społeczne. Nie zmienia to jednak faktu, iż również w tym przypadku ważna jest dobra wola. Z kolei historia Kościołów chrześcijańskich w Iraku pokazuje, że nie ponoszą one winny za obecny stan rzeczy.

Za sytuację, w której doszło do powstania Państwa Islamskiego nie ponoszą odpowiedzialności poszczególne religie, ale raczej zwykła chęć dominacji. Dlatego warto przytoczyć słowa Hamida Algabid ${ }^{84}$, który pisał, że jeszcze dziś chrześcijanie i muzutmanie obawiaja się przedtużenia tych tragedii, których

\footnotetext{
${ }^{82}$ A. G i a n e 11 i, A. T o r n i e 11 i: Papieże a wojna. Od pierwszego światowego konfliktu do ataku na Irak. Przeł. L. R o d z i e w i c z. Kraków 2006 s. 312-317.

${ }^{83}$ W. H a j n u s: Mój Irak. Poznań 2009 s. 71n

${ }^{84}$ Sekretarz generalny organizacji Konferencji islamskiej.
} 
owocem były już całe pokolenia męczenników, zwłaszcza na Bliskim Wschodzie, oraz tego, że narody regionu tak drogiego nam, ludziom wierzacym, będa musiaty nadal płacić za popetnione niesprawiedliwości i za nierówności ${ }^{85}$, mając nadzieję, że kiedyś przestaną być aktualne.

${ }^{85}$ List Sekretarza Generalnego Organizacji Konferencji Islamskiej do Papieża, Jeddah, 4 marca 1991. W: Islam w dokumentach Kościoła i nauczaniu Jana Pawła II (1965-1996). Red. E. S a k o w i c z. Warszawa 1997 s. 203. 